\title{
LRRK2 Gene
}

National Cancer Institute

\section{Source}

National Cancer Institute. LRRK2 Gene. NCI Thesaurus. Code C78154.

This protein may play a role in the modulation of protein phosphorylation. 